\title{
ANALISIS RISIKO LIKUIDITAS DAN PROFITABILITAS PADA PERUSAHAAN YANG MELAKUKAN AKUISISI YANG TERDAFTAR DI BURSA EFEK INDONESIA
}

\author{
R Gatot Heru Pranjoto \\ Program Studi Manajemen Universiitas Trunojoyo Madura \\ pranjotogatot@Gmail.Com
}

\begin{abstract}
The company's goal is to achieve maximum profit, through earning power, which is marked by increased profit margins and total assets turn over. The company's operations must be able to produce sales units as high as each unit of company assets, on the other hand each sales unit must be able to produce operating profits as high as high. In addition to the concept of maximum profit the company must be able to achieve high efficiency through the concept of profitability. High efficiency can be measured by the concept of profitability, namely by comparing the amount of net income generated by using company capital. With high profitability, it is hoped that company synergy can be achieved.
\end{abstract}

Key words: Earning Power, Profit Margin, Total Aset Turn Over.

\section{PENDAHULUAN}

Diera pasar global, perusahaan harus dapat menjalankan operasionalnya secara efisiensi, serta laba maksimal . laba maksimal dapat dicapai jika perusahaan dapat memenangkan persaingan dipasar. Perusahaan dapat memenangkan persaingan dipasar jika perusahaan dapat melakukan perbaikan secara terus menerus, sehingga produk yang dihaslkan sesuai dengan selera dan permintaan konsumen.

Operasinal perusahaan serta melakukan perbaikan secara terus menerus, memerlukan dana yang besar, adapun sumber dana yang dapat digunakan yaitu berasal dari menggunakan modal sendiri, yang berasal dari menjual saham biasa atau menggunakan sumber yang lain seperti laba ditahan. Selain menggunakan 
komponen modal sendiri, perusahaan dapat menggunakan sumber pendanaan yang berasal dari hutang, baik hutang yang berasal dari perbankan atau menggunalan surat berharga seperti obligasi.

Penggunaan sumber pendanaan tersebut tentu mempunyai konsekuensi tersendiri dari masing masing sumber pendanaan yang digunakan. Jika perusahaan menggunakan sumber pendanaan dari hutang, maka konsekuensinya perusahaan harus menanggung beban tetap, seperti bunga. Dilai pihak ika perusahaan menggunakan sumber pendanaan yang berasal dari modal sendiri, suatu misal perusahaan menjuala saham biasa, maka konsekuensinya perusahaan harus membayar dividen kepada para pemegang atau pemilik perusahaan.

Apapun sumber pendanaan yang digunakan oleh perusahaan, para investor mempunyai kepentingan yang menguntungkan bagi dirinya, yangdapat diukur melalui earning pershare (EPS) dan return on equity (ROE). Untuk dapat memperoleh earning pershare (EPS) dan return on equity (ROE), yang menguntungkan maka para eksekutif serta pemilik perusahaan harus sepakat untuk dapat menggunakan sistem pengendalian manajemen perusahaan dengan baik

\section{TINJAUAN TORI}

\subsection{Proporsi Penggunaan Hutang ditinjau dari ROE}

Tingkat pengembalian equitas (Return on equity-ROE), merupakan perbandingan antara laba bersih setelah pajak atau earning after taxes (EAT) dengan modal sendiri (equity). Nilai return on equity (ROE), semakin besarsemakin menguntungkan bagi pemegang saham biasa, sumber pembelanjaan perusahaan diperkenankan menggunakan hutang apabila :

1. Penambahan modal asing (hutang) diperkenankan apabila ROE yang dihasilkan dengan penambahan hutang tersebut lebih besar jika dibandingkan dengan ROE yang dihasilkandari penambahan equitas atau modal sendiri, atau

2. Penambahan hutang tidak diperkenankan apabila tingkat pengembaliannya $<$ dari suku bunga hutang. 


\section{Contoh kasus}

Suatu perusahaan beroperasi dengan Modal saham biasa senilai Rp 60 juta yang terdiri dari 1 juta lembar, dimana Tahun depan diperkirakan perusahaan akan meningkatkan EBIT menjadi Rp 20 juta, untuk itu, perusahaan akan menambah dana untuk membeli mesin, yaitu sebesar Rp 15 juta, pemenuhan kebutuhan dana tersebut dapat melalui berbagai sumber dana antara lain :

a. pinjam bank dengan suku bunga $20 \%$ pertahun merata

b. emisi saham baru dengan dengan harga Rp 60 perlembar

Alternatif sumber pembelanjaan mana yang sebaiknya dipilih agar return on equity (ROE) yang dihasilkan menguntungkan para pemegang saham perusahaan?

\section{Pemecahan :}

1. Jumlah dana keseluruhan setelah penambahan adalah 60 juta +15 Juta $=75$ juta, dengan EBIT sebesar 20 juta

2. Jadi tambahan dana 15 juta mrpk $20 \%$ dari dana keseluruhan, jadi EBIT yang menjadi bagian tambahan dana 15 juta adalah 20\%(20 juta) yaitu 4 juta

3. Jadi tingkat pengembalian dari tambahan dana tersebut 4 juta/15 juta $=$ $26,67 \%$

4. Tingkat pengembalian sebesar $26,6 \%$ dibandingkan dengan besarnya suku bunga yang berlaku, dalam hal ini akan muncul berbabai kemungkinan perbandingan antara tingkat pengembalian dengan suku bunga yang berlaku, antara lain suku bunga > tingkat pengembalian, suku bunga $<$ tingkat pengembalian, suku bunga $=$ tingkat pengembalian

\subsubsection{Perhitungan EPS dan ROE,}

jika Dengan asumsi tingkat suku bunga 20\% < Tingkat pengembalian 26,67\%, maka hasil perhitungan EPS dan ROE, nampak sebagai berikut : 


\begin{tabular}{|l|r|r|}
\hline \multicolumn{1}{|c|}{ Uraian } & Dana Perbankan & \multicolumn{1}{c|}{ Emisi Saham } \\
\hline EBIT & Rp $20000000,-$ & Rp $20000000,-$ \\
\hline Bunga $20 \%$ & $17000000,-$ & $000,-$ \\
\hline EBT & $1700000,-$ & $20000000,-$ \\
\hline Pajak $10 \%$ & $15300000,-$ & $18000000,-$ \\
\hline EAT & $60000000,-$ & $75000000,-$ \\
\hline Modal Sendiri & 1000000 & 1250000 \\
\hline $\begin{array}{l}\text { Lembar } \\
\text { Saham }\end{array}$ & 15,30 & 14,40 \\
\hline $\begin{array}{l}\text { Laba } \\
\text { persaham }\end{array}$ & $25,5 \%$ & $24,00 \%$ \\
\hline ROE & & \\
\hline
\end{tabular}

Dengan asumsi jika suku bunga lebih kecil dari tingkat pengembalian maka sebaiknya pemenuhan kebutuhan dana sebesar Rp 15 juta untuk membeli mesin, sebaiknya dipenuhi dengan meminjam dana perbankan karena alternative pembelanjaan tersebut memberikan laba persaham dan tingkat pengembalian equitas yang lebih besar jika dibandingkan dengan pemenuhan kebutuhan dana dengan menerbitkan saham, seperti nampak pada perhitungan diatas.

\subsubsection{Perhitungan EPS dan ROE,}

jika Dengan asumsi tingkat suku bunga $26,67 \%=$ Tingkat pengembalian $26,67 \%$, maka hasil perhtungan EPS dan ROE nampak sebagai berikut :

\begin{tabular}{|l|r|r|}
\hline \multicolumn{1}{|c|}{ Uraian } & \multicolumn{1}{c|}{ Dana Perbankan } & \multicolumn{1}{c|}{ Emisi Saham } \\
\hline EBIT & Rp $20000000,-$ & Rp $20000000,-$ \\
\hline Bunga $20 \%$ & $4000000,-$ & 0 \\
\hline EBT & $16000000,-$ & $20000000,-$ \\
\hline Pajak $10 \%$ & $1600000,-$ & $2000000,-$ \\
\hline EAT & $14400000,-$ & $18000000,-$ \\
\hline
\end{tabular}




\begin{tabular}{|l|r|r|}
\hline Modal Sendiri & $60000000,-$ & $75000000,-$ \\
\hline Lembar & 1000000 & 1250000 \\
Saham & 14,40 & 14,40 \\
\hline $\begin{array}{l}\text { Laba } \\
\text { persaham }\end{array}$ & & \\
\hline ROE & $24,00 \%$ & $24,00 \%$ \\
\hline
\end{tabular}

Dari uraian perhitungan diatas nampak jika suku bunga yang berlaku sama dengan tingkat pengembalian, maka pemenuhan kebutuhan dana sebesar Rp 15 juta, dapat dipenuhi dengan meminjam dana perbankan atau dipenuhi dengan menerbitkan saham, akan menghasilkan laba persaham dan Return On Equity (ROE) yang besarnya sama untuk kedua alternative pembelanjaan.

\subsubsection{Perhitungan EPS dan ROE,}

jika Dengan asumsi tingkat suku bunga 30\% > Tingkat pengembalian 26,67\%, maka hasil perhitungan EPS dan ROE nampak sebagai berikut :

\begin{tabular}{|l|r|r|}
\hline \multicolumn{1}{|c|}{ Uraian } & Dana Perbankan & \multicolumn{1}{c|}{ Emisi Saham } \\
\hline EBIT & Rp $20000000,-$ & Rp $20000000,-$ \\
\hline Bunga $20 \%$ & $4500000,-$ & $20000000,-$ \\
\hline EBT & $15500000,-$ & $2000000,-$ \\
\hline Pajak 10\% & $1550000,-$ & $18000000,-$ \\
\hline EAT & $13950000,-$ & $75000000,-$ \\
\hline Modal Sendiri & $1000000,-$ & 1250000 \\
\hline $\begin{array}{l}\text { Lembar } \\
\text { Saham }\end{array}$ & 13,95 & 14,40 \\
\hline $\begin{array}{l}\text { Laba } \\
\text { persaham }\end{array}$ & $23,25 \%$ & \\
\hline ROE & & \\
\hline
\end{tabular}


Dari uraian perhitungan diatas nampak bahwa jika suku bunga lebih besar dari tingkat pengembalian maka sebaiknya pemenuhan kebutuhan dana sebesar Rp 15 juta, dapat dipenuhi dengan penerbitan saham biasa karena dapat memberikan laba persaham dan tingkat pengembalian equitas (ROE) yang lebih besar jika dibandingkan dengan pemenuhan pembelanjaan menggunakan dana perbankan.

\subsection{Hubungan Antara Proporsi Penggunaan Hutang Terhadap \\ Likuiditas.}

Penggunaan hutang oleh perusahaan harus tetap mempertimbangkan kelancaran operasional perusahaan, dalam arti perusahaan harus tetap dapat memenuhi segala kewajibannya baik kewajiban jangka panjang maupun jangka pendek, untuk itu perusahaan harus mempertimbangkan aspek rentabilitas ekonomisnya yaitu perbandingan antara besarnya laba kotor terhadap besarnya bunga sebagai akibat penggunaan hutang.

1. Dengan penggunaan hutang, likuiditas perusahaan harus tetap terjaga.

2. Dengan penggunaan hutang perusahaan dibebani biaya tetap yaitu pokok angsuran + bunga

3. Untuk mengetahui timbul kesulitan likuiditas atau tidak, maka digunakan pendekatan Debt Service Coverage (DSC), sebagai berikut :

Laba sebelum bunga dan pajak

Beban bunga $+\underline{\text { Pokok pinjaman }}$

$$
\text { (1-pajak) }
$$

\section{Contoh kasus}

Perusahaan Linggar Jati tahun lalu memperoleh laba sebelum bunga dan pajak Rp 12 juta,beban bunga yang harus dibayar Rp 1,5 juta sedangkan pokok pinjaman Rp 2,7 juta, diasumsikan tarif pajak 10\%, maka DSC :

$\underline{\operatorname{Rp} 12000000}$

$\operatorname{Rp} 1500000+\underline{\operatorname{Rp} 2700000}=2,6$ 
Yang menjadi pertanyaan, bagaimana pengaruhnya Debt Service Coverage (DSC) sebesar 2,6 terhadap besarnya earning before interest taxes (EBIT) yang dicapai perusahaan? Dalam hal ini Debt Service Coverage (DSC), sebesar 2,6 berarti bahwa :

a. Maksimum penurunan earning before interest taxes (EBIT), adalah sebesar $1 /(1: 2,6)=0,62 \%$

b. Jika penurunan earning before interest taxes (EBIT melebihi 0,62\%, maka akibatnya laba kotor atau earning before interest taxes (EBIT ) yang dihasilkan akan lebih kecil dari beban tetap yaitu pokok + bunga

Sehingga merupakan suatu keharusan bahwa :

1. Besarnya Debt Service Coverage (DSC) harus lebih besar dari 1 agar likuiditas perusahaan tidak terganggu, karena aliran kas masuk lebih besar dari beban tetap.

2. Jika Debt Service Coverage (DSC) kurang dari 1 maka likuiditas perusahaan akan terganggu, karena aliran kas masuk akan lebih kecil dari beban tetap.

\subsection{Pengaruh Proporsi Hutang Terhadap Return On Equity (ROE)}

Untuk mengetahui pengaruh proporsi hutang terhadap return on equity (ROE), maka harus memperhatikan besarnya return on investment (ROI), yaitu perbandingan antara laba kotor (EBIT) terhadap total asset, mengapa demikian karena berapapun besarnya tingkat pengembalian yang diinginkan sangat tergantung pada besarnya investasi yang digambarkan oleh besarnya total asset, dan perusahaan mempunyai kewajiban bagaimana dengan besarnya investasi tersebut perusahaan dapat menghasilkan laba kotor (EBIT) yang semaksimal mungkin. Semakin besar return on investment (ROI),adalah semakin bagus. Oleh karena pembahasan kita kali ini berhubungan dengan penggunaan hutang dan konsekwensi penggunaan hutang perusahaan dibebani bunga, maka dalam pembahasan ini return on investment (ROI) harus dibandingkan dengan besarnya tingkat bunga yang berlaku. 


\subsubsection{Penghitungan ROE $d g$ asumsi ROI $=20 \%>$ Tingkat bunga $15 \%$}

Untuk mengetahui besarnya Return On Equity (ROE) dengan berbagai alternative perbandingan antara Return On Investment (ROI) terhadap tingkat bunga, maka perlu dilihat terlebih dahulu besarnya elemen seperti total asset, hutang (debt) dengan besarnya Equity (E), didalam hal ini untuk alternative 1 , besarnya asset sebesar Rp 20 000,-, equity sebesar Rp 16 000,- dan hutang atau debt sebesar Rp 4 000,-, sehingga dapat diketahui besarnya Debt to Equity (D/E) sebesar 25\% dan Debt to Asset (D/A) sebesar $20 \%$, dengan komposisi ketiga elemen tersebut, ternyata menghasilkan Return On Investment (ROI) sebesar 20,0 \% yang lebih besar jika dibandingkan dengan tingkat bunga pasar sebesar 15\%, dengan demikian maka jika pada alternative 1 dengan komposisi $\mathrm{D} / \mathrm{E}$ dan $\mathrm{D} / \mathrm{A}$ sedemikian rupa maka akan menghasilkan Return On Equity (ROE) sebesar 19,1 \%, demikian dan seterusnya untuk alternative struktur 2 dan struktur 3, berturutturut akan mengasilkan Return On Equity (ROE) sebesar 22,5\% untuk struktur ke 2 dan struktur 3 menghasilkan Return On Equity (ROE) sebesar $36,0 \%$

\begin{tabular}{|c|c|c|c|}
\hline & Struktur -1 & Struktur-2 & Struktur-3 \\
\hline Uraian & $\mathrm{D} / \mathrm{E} 25 \%, \mathrm{D} / \mathrm{A} 20 \%$ & $\mathrm{D} / \mathrm{E} 100 \%, \mathrm{D} / \mathrm{A} 50 \%$ & $\mathrm{D} / \mathrm{E} 400 \%, \mathrm{D} / \mathrm{A} 80 \%$ \\
\hline EBIT & Rp 4 000,- & Rp 4 000,- & Rp $4000,-$ \\
\hline Bunga $15 \%$ & $600,-$ & $1500,-$ & $2400,-$ \\
\hline EBT & $3400,-$ & $2500,-$ & $1600,-$ \\
\hline Pajak 10\% & $340,-$ & $250,-$ & $160,-$ \\
\hline EAT & $3060,-$ & $2250,-$ & $1440,-$ \\
\hline Debt & $4000,-$ & $10000,-$ & $16000,-$ \\
\hline Equity & $16000,-$ & $10000,-$ & $4000,-$ \\
\hline Aset & $20000,-$ & $20000,-$ & $20000,-$ \\
\hline $\mathrm{ROE}=\mathrm{EAT} / \mathrm{E}$ & $19,1 \%$ & $22,5 \%$ & $36,0 \%$ \\
\hline $\mathrm{ROI}=\mathrm{EBIT} / \mathrm{A}$ & $20,0 \%$ & $20,0 \%$ & $20,0 \%$ \\
\hline
\end{tabular}


Dengan demikian dapat disimpulkan bahwa jika Return On Investment (ROI) lebih besar dari tingkat bunga maka penggunaan pembelanjaan hutang yang lebih kecil dari equity maka akan menghasilkan Return On Equity (ROE) sebesar 19,1\%, tetapi jika penggunaan pemebelanjaan hutang lebih besar dari equity (struktur 3) maka akan menghasilkan Return On Equity (ROE) yang lebih besar dari struktur 1 yaitu sebesar 36,0\%, berikutnya kita akan melihat jika kondisi dipasar menunjukkan bahwa tingkat bunga $=$ ROI seperti nampak pada sub bahasan 8.4.2. berikut :

\subsubsection{Penghitungan ROE dg asumsi ROI $=15 \%=$ Tingkat bunga $15 \%$}

\begin{tabular}{|c|c|c|c|}
\hline & Struktur -1 & Struktur-2 & Struktur-3 \\
\hline Uraian & $\mathrm{D} / \mathrm{E} 25 \%, \mathrm{D} / \mathrm{A} 20 \%$ & $\mathrm{D} / \mathrm{E} 100 \%, \mathrm{D} / \mathrm{A} 50 \%$ & $\mathrm{D} / \mathrm{E} 400 \%, \mathrm{D} / \mathrm{A} 80 \%$ \\
\hline EBIT & Rp $3000,-$ & Rp 3 000,- & Rp $3000,-$ \\
\hline Bunga $15 \%$ & $600,-$ & $1500,-$ & $2400,-$ \\
\hline EBT & $2400,-$ & $1500,-$ & $600,-$ \\
\hline Pajak 10\% & $240,-$ & $150,-$ & 60 ,- \\
\hline EAT & $2160,-$ & $1350,-$ & $540,-$ \\
\hline Bebt & $4000,-$ & $10000,-$ & $16000,-$ \\
\hline Equity & $16000,-$ & $10000,-$ & $4000,-$ \\
\hline Aset & $20000,-$ & $20000,-$ & $20000,-$ \\
\hline $\mathrm{ROE}=\mathrm{EAT} / \mathrm{E}$ & $13,5 \%$ & $13,5 \%$ & $13,5 \%$ \\
\hline $\mathrm{ROI}=\mathrm{EBIT} / \mathrm{A}$ & $15,0 \%$ & $15,0 \%$ & $15,0 \%$ \\
\hline
\end{tabular}

Ternyata dari hasil perhitungan nampak bahwa jika tingkat suku bunga dipasar sebesar 15\% sama dengan Return On Investment (ROI) sebesar $15 \%$, maka akan menunjukkan bahwa berbagai alternative penggunaan sumber pembelanjaan antara hutang dan equity, apakah pembelanjaan hutang lebih kecil dari equity dan sebaliknya, maka akan menghasilkan Return On Equity (ROE) yang sama yaitu sebesar 13,5 \% , lalu bagaimana jika tingkat bunga pasar lebih kecil dari Return On Investment (ROI), maka hasil perhitungannya akan nampak sebagai berikut : 
2.3.3. Penghitungan ROE dg asumsi ROI $=12,5 \%<$ Tingkat bunga $15 \%$

\begin{tabular}{|c|c|c|c|}
\hline & Struktur -1 & Struktur-2 & Struktur-3 \\
\hline Uraian & $\mathrm{D} / \mathrm{E} 25 \%, \mathrm{D} / \mathrm{A} 20 \%$ & $\mathrm{D} / \mathrm{E} 100 \%, \mathrm{D} / \mathrm{A} 50 \%$ & $\mathrm{D} / \mathrm{E} 400 \%, \mathrm{D} / \mathrm{A} 80 \%$ \\
\hline EBIT & Rp 2 500,- & Rp 2 500,- & Rp 2 500,- \\
\hline Bunga $15 \%$ & $600,-$ & $1500,-$ & $2400,-$ \\
\hline EBT & $1900,-$ & $1000,-$ & $100,-$ \\
\hline Pajak 10\% & $190,-$ & $100,-$ & $10,-$ \\
\hline EAT & $1710,-$ & $900,-$ & $90,-$ \\
\hline Debt & $4000,-$ & $10000,-$ & $16000,-$ \\
\hline Equity & $16000,-$ & $10000,-$ & $4000,-$ \\
\hline Aset & $20000,-$ & $20000,-$ & $20000,-$ \\
\hline $\mathrm{ROE}=\mathrm{EAT} / \mathrm{E}$ & $10,7 \%$ & $9,0 \%$ & $2,25 \%$ \\
\hline $\mathrm{ROI}=\mathrm{EBIT} / \mathrm{A}$ & $12,5 \%$ & $12,5 \%$ & $12,5 \%$ \\
\hline
\end{tabular}

Dari hasil perhitungan nampak bahwa jika tingkat bunga lebih besar dari Return On Investment (ROI), maka alternative pembelanjaan hutang yang lebih kecil dari equity maka akan menghasilkan Return On Equity (ROE) sebesar 10,7 \% yang lebih besar jika menggunakan alternative pembelanjaan sebaliknya yaitu komposisi hutang lebih besar dari equity yang menghasilkan Return On Equity (ROE) lebih kecil yaitu sebesar 2,25 $\%$, jadi secara keseluruhan dapat disimpulkan bahwa :

1. Apabila ROI >tingkat bunga, maka dengan proporsi hutang yang semakin tinggi akan berpengaruh positif yang semakin besar terhadap ROE

2. Apabila $\mathrm{ROI}=$ tingkat bunga, maka dengan proporsi hutang berapapun akan menghasilkan ROE yang sama

3. Apabila ROI < tingkat bunga, maka dengan proporsi hutang yang semakin tinggi akan berpengaruh negatif yang semakin besar terhadap ROE 


\section{Kasus}

Sebuah industri perakitan barang elektronik,daerah pemasarannya $60 \%$ ditujukan untuk negara asean, sedangkan sisanya untuk memenuhi permintaan dalam negeri, Sebagai seorang konsultan keuangan saudara diminta untuk menganalisa berbagai alternatif sumber pembelanjaan untuk investasi peralatan perakitan modern, Informasi yang didapat dari manajer keuangan dan akuntansi, bahwa EBIT sebesar 600 juta dengan komposisi modal sebagai berikut :

Komposisi modal

Saham biasa@Rp 15 000,- Rp 600 juta

Saham preferen $12 \% \quad 300$ juta

Laba ditahan 250 juta

Jumlah modal sendiri $\quad$ Rp 1150 juta

1. Tingkat penjualan sangat peka terhadap gerakan pasar yang disebabkan perkembangan teknologi

2. Untuk mengantisipasi lonjakan teknologi perusahaan membutuhkan tambahan dana sebesar Rp 750 juta untuk peralatan

3. Dengan peralatan tersebut EBIT dapat ditingkatkan menjadi Rp 800 juta.

Ada 2 alternatif sumber pendanaan

1. Sejumlah $60 \%$ bersumber dari pinjaman bank dengan tingkat bunga $18 \%$ pertahun merata, sisanya emisi saham biasa dengan harga bersih setelah dikurangi biaya yaitu sebesar Rp 20 000,-perlembar

2. Sejumlah $60 \%$ emisi saham biasa dengan harga bersih Rp 20000 perlembar, sedang sisanya pinjam bank dengan bunga 18\% pertahun merata.

3. Saudara diminta membuat kertas kerja yang jelas dan lengkap tentang alternatif sumber pendanaan mana yang akan dipilih, dengan asumsi tarif pajak rata-rata $27,5 \%$ 


\section{Pemecahan :}

Untuk membahas alternative, apakah pemenuhan dana dibelanjai dengan pinjam dana perbankan atau mengeluarkan (emisi) saham baru pengaruhnya terhadap Return On Equity (ROE) atau Laba persaham (EPS), dapat dihitung sebagai berikut :

\begin{tabular}{|c|c|c|}
\hline \multirow[b]{2}{*}{ Uraian } & \multicolumn{2}{|c|}{ Alternatif Pembelanjaan } \\
\hline & $\begin{array}{l}\text { Dana Perbankan } 60 \%, \\
\text { Emisi saham } 60 \%\end{array}$ & $\begin{array}{l}\text { Emisi saham } 40 \%, \\
\text { Dana Perbankan } 40 \%\end{array}$ \\
\hline EBIT & $\operatorname{Rp} 800000$ 000,- & Rp $800000000,-$ \\
\hline Bunga $18 \%$ & $81000000,-$ & $54000000,-$ \\
\hline EBT & $719000000,-$ & $746000000,-$ \\
\hline Pajak 27\% & $197725000,-$ & $205150000,-$ \\
\hline EAT & $521275000,-$ & $540850000,-$ \\
\hline Dividen P'St & $36000000,-$ & 26000000 \\
\hline EAT Unt C'St & $485275000,-$ & $504850000,-$ \\
\hline Jml Modal Sendiri & $1450000000,-$ & $1600000000,-$ \\
\hline Jml Lembar Saham & 55000 & 62500 \\
\hline EPS & 8823,18 & 8077,60 \\
\hline ROE & $35,95 \%$ & $33,80 \%$ \\
\hline
\end{tabular}

Jumlah modal sendiri $=1150000+300000=1450000$

Jumlah lembar saham $=(600$ juta $: 15000)+(300$ juta:20 000 $)=55000$ lembar

Dari hasil perhitungan maka dapat disimpulkan bahwa didalam memenuhi kebutuhan dana sebaiknya perusahaan memilih alternatif 1 yaitu :

a. Pinjam bank $60 \%$ yaitu sebesar $60 \%$ (750 juta) $=$ Rp 450000 $000,-$

b. Emisi saham biasa $40 \%$, yaitu sebesar $40 \%(750$ juta $)=R p 300000$ 000,- 
c. Karena alternative pembelanjaan ini menghasilkan EPS dan ROE lebih tinggi jika dibandingkan dengan alternative pembelanjaan yang lain.

\section{Kasus}

United Batteray Corporation (UBC) menghasilkan sejenis produk baterai berumur panjang dan dapat diisi ulang untuk kalkulator kecil.Berikut laporan laba rugi PT UBC adalah sebagai berikut :

Penjualan bersih 500000 unit @ Rp 20 Rp 10000 000,-

Biaya variabel Rp 8 perunit

Biaya tetap

EBIT

Bunga

EBT

Pajak 25\%

EAT

EPS (100 $000 \mathrm{lb})$

$$
4000000,-
$$

$2000000,-$

$4000000,-$

$1250000,-$

$2750000,-$

$687500,-$

$2062500,-$

20,625

Perusahaan ingin meningkatkan volume produksi dengan membeli mesin baru yang otomatis dan modern, unt itu biaya tetap naik 100\%, tetapi biaya variabel perunit turun menjadi Rp 5,-, bila mesin baru tersebut dibiayai dg obligasi maka bunga meningkat sebesar Rp 750 000,- dan bila dibiayai dengan emisi saham biasa, maka total saham yg beredar meningkat 25000 $\mathrm{lb}$, asumsi tingkat penjualan naik $10 \%$, tentukan alternatif mana yg dipilih unt membiayai perubahan menuju produksi baru tersebut 


\section{Pemecahan}

\begin{tabular}{|l|l|l|}
\hline Uraian & Dana Obligasi & Emisi Saham \\
\hline Penjualan 550000 unit @ 20 & Rp $11000000,-$ & Rp $11000000,-$ \\
\hline Biaya Variabel $2750000,-$ & & \\
\hline Biaya Tetap $4000000,-$ & & \\
\hline Total Biaya & $6750000,-$ & $6750000,-$ \\
\hline EBIT & $4250000,-$ & $4250000,-$ \\
\hline Bunga & $2000000,-$ & $1250000,-$ \\
\hline EBT & $2250000,-$ & $3000000,-$ \\
\hline Taxes 25\% & $562500,-$ & $750000,-$ \\
\hline EAT & $1687500,-$ & $2250000,-$ \\
\hline Lembar Saham & 100000 & 125000 \\
\hline EPS & 16,87 & 18,00 \\
\hline
\end{tabular}

Keinginan perusahaan untuk meningkatkan volume produksi, dengan membeli mesin baru, sebaiknya menggunakan alternatif 2, yaitu emisi saham biasa 100\% karena laba persahamnya sebesar Rp 18 lebih besar jika menggunakan alternative pembelanjaan obligasi, yaitu sebesar Rp 16,87

\subsection{Struktur Sistem Pengawasan Manajemen}

Sistem pengawasan manajemen terdiri dari struktur atau kerangka serta proses, dimana keangka sistem terdiri dai bagian bagian yang membentuk sistem tersebut, sedang suatu proses sistem menjelaskan bekerjanya tiap tiap bagian dalam sistem untuk mencapai tujuan sistem tersebut.

Kerangka sistem pengawasan manajemen terdiri dari unit unit dalam organisasi yang berupa pusat pusat peranggungjawaban dan ukuran yang digunakan untuk meilai prestasi tiap tiap manajer pusat pertanggungjawaban tersebut.proses sistem pengawasan manajemen terdiri dari empat tahap sebagai berikut :
a. Penyusunan progam
b. Penyusunan anggaran 
c. Pelaksanaan dan pengukuran

d. Pelaporan dan analisa

Pusat peranggungjawaban (Resposibility Center), adalah unit oganisasi yang dikepalai oleh seorang manajer yang bertanggungjawab, adapun kegiatan pusat pertanggungjawaban adalah terdiri dari pengolahan masukan (input) menjadi output yang berupa produk atau jasa, yang selanjutnya produk tersebut akan mengalir kepada pusat pertanggungjawaban yang lain atau kepada para langganan diluar perusahaan.

\section{METODE PENELITIAN}

\subsection{Populasi Dan Penentuan Sampel.}

Penelitian ini dilakukan pada perusahaan yang terdaftar di Bursa Eefek Indonesia, yang melakukan akuisisi pada tahun 2014, yaitu sebanyak 10 perusahaan

\subsection{Variable Terukur.}

1. Return On Net Worth, yaitu perbandingan antara laba bersih setelah pajak dengan total aset.

2. Return On Equity, yaitu tingkat pengembalian yang diperuntukkan bagi pemilik modal sendiri., yaitu perbandingan antara laba bersih setelah pajak dengan modal sendiri.

3. Net Profit Margin, yaitu perbandingan antara laba bersih setelah pajak dengan penjualan.

\subsection{Prosedur Pengambilan dan Pengumpulan Data}

Untuk pengumpulan data yang diperlukan dalam penelitian, peneliti menggunakan metode pengumpulan data library reseach, yaitu merupakan metode pengumpulan data yang diperoleh dengan cara penelitian kepustakan, yaitu diperoleh melalui buku-buku pustaka sebagai bahan kajian untuk membahas permasalahan yang diteliti. 


\subsection{Perbedaan Sebelum Dan Sesudah Akuisisi}

Untuk mengetahui perbedaan variabel yang dihitung yaitu return on net worth, return on equity dan net profit margin, sebelum dan sesudah melakukan akuisisi dilakukan dengan membandingkan rasio sebelum dan sesudah melakukan akuisisi, melalui uji $\mathrm{T}$, dengan menggunakan SPSS, uji Wilxocon.

\section{PEMBAHASAN}

\subsection{Return On Investment}

Retun on investment,merupakan perbandingan antara laba bersih setelah pajak dibagi dengan total aset, jadi return on investment menunjukkan besarnya laba yang dihasilkan oleh penggunaan total aset perusahaan.

Tabel 4.1. Return On Investment Perusahaan Yang Terdaftar Di Bursa Efek Indonesia Tahun 2011 - 2017 (000 000)

\begin{tabular}{|l|l|l|l|l|l|l|l|l|}
\hline \multirow{2}{*}{ No } & \multirow{2}{*}{ Kode } & \multirow{2}{*}{ Perusahaan } & \multicolumn{7}{|c|}{ Tahun } \\
\cline { 5 - 9 } & & 2011 & 2012 & 2013 & 2015 & 2016 & 2017 \\
\hline 1. & AALI & PT Astra & 0,25 & 0,21 & 0,14 & 0,04 & 0,10 & 0,09 \\
\hline 2 & AISA & PT.Tiga P & 0,04 & 0,07 & 0,07 & 0,04 & 0,08 & $-0,10$ \\
\hline 3. & APLN & PT.Agung.P & 0,02 & 0,11 & 0,12 & 0,05 & 0,04 & 0,27 \\
\hline 4. & ASII & PT Astra I & 0,14 & 0,58 & 0,46 & 0,27 & 0,09 & 0,08 \\
\hline 5. & PTBA & PT.Bukit A & 0,27 & 0,23 & 0,16 & 0,13 & 0,12 & 0,21 \\
\hline 6. & MDLN & PT Modernland & 0,03 & 0,06 & 0,25 & 0,08 & 0,03 & 0,04 \\
\hline 7. & XL & PT.XL Asia & 0,10 & 0,08 & 0,03 & $-0,42$ & 0,68 & 0,68 \\
\hline 8. & INTP & PT Indocement & 0,20 & 0,21 & 0,20 & 0,17 & 0,13 & 0,07 \\
\hline 9. & SIMP & PT Salim Ivo & 0,09 & 0,05 & 0,02 & 0,01 & 0,02 & 0,03 \\
\hline 10. & META & PT.Nusantara & $-0,02$ & 0,02 & 0,03 & 0,04 & 0,04 & 0,03 \\
\hline
\end{tabular}

Sumber : Bursa Efek Indonesia (Data Diolah)

Pada tabel 4.1. nampak bahwa besarnya return on investment 10 perusahaan sebelum maupun sesudah akuisisi berfluktuasi, hal ini menunjukkan bahwa apabila dalam operasinya, perusahaan menambah hutang, maka akan berdampak berfluktuasinya return on equity. Besar 
kecilnya Return on investment tergantung dari net profit margin dan perputaran aktiva, jadi jelas fokus utama operasional perusahaan harus menghasilkan penjualan setinggi tingginya.

\begin{tabular}{|l|r|}
\hline Asymp. Sig. (2-tailed) & 0,092 \\
\hline
\end{tabular}

Dengan menggunakan uji Wilxocon, menujukkan bahwa return on investment secara keseluruhan, baik sebelum maupun sesudah akuisisi berbeda secara signifikan

\subsection{Return On Equity.}

Return on equity, meunjukkan besarnya laba bersih setelah pajak yang dihasilkan oleh besanya modal sendiri yang dipakai perusahaan. Besar kecilnya return on equity, berhubungan dengan rentabilitas ekonomi.

Tabel 4.2. Return On Equity Perusahaan Yang Terdaftar Di Bursa Efek Indonesia Tahun 2011-2017 ( 000 000)

\begin{tabular}{|l|l|l|l|l|l|l|l|l|}
\hline \multirow{2}{*}{ No } & \multirow{2}{*}{ Kode } & \multirow{2}{*}{ Perusahaan } & \multicolumn{7}{|c|}{ Tahun } \\
\cline { 5 - 9 } & & & 2011 & 2012 & 2013 & 2015 & 2016 & 2017 \\
\hline 1. & AALI & PT Astra & 0,30 & 0,28 & 0,19 & 0,06 & 0,12 & 0,11 \\
\hline 2 & AISA & PT.Tiga P & 0,09 & 0,12 & 0,15 & 0,10 & 0,17 & $-0,54$ \\
\hline 3. & APLN & PT.Agung.P & 0,05 & 0,20 & 0,23 & 0,12 & 0,10 & 0,16 \\
\hline 4. & ASII & PT Astra I & 0,29 & 0,25 & 0,21 & 0,13 & 0,16 & 0,14 \\
\hline 5. & PTBA & PT.Bukit A & 0,38 & 0,34 & 0,26 & 0,22 & 0,20 & 0,33 \\
\hline 6. & MDLN & PT Modernland & 0,07 & 0,12 & 0,52 & 0,15 & 0,76 & 0,10 \\
\hline 7. & XL & PT.XL Asia & 0,21 & 0,18 & 0,07 & $-0,02$ & 0,02 & 0,03 \\
\hline 8. & INTP & PT Indocement & 0,23 & 0,25 & 0,22 & 0,18 & 0,15 & 0,10 \\
\hline 9. & SIMP & PT Salim Ivo & 0,15 & 0,10 & 0,04 & 0,03 & 0,03 & 0,04 \\
\hline 10. & META & PT.Nusantara & $-0,03$ & 0,05 & 0,05 & 0,08 & 0,08 & 0,05 \\
\hline
\end{tabular}

Sumber : Bursa Efek Indonesia (Data Diolah).

Dimana rentabilitas ekonomi menunjukkan perkalian antara profit margin dengan perputaran aktiva. 
Return on equity perusahaan yang terdaftar di bursa efek indonesia baik sebelum maupun sesudah akuisisi umumnya berfluktuasi, jadi untuk meningkatkan sinergi perusahaan terutama setelah akuisisi, maka ada dua fokus utama yang harus dicapai perusahaan untuk meningkatkan return on equity, yaitu efisiensi semaksimal mungkin, artinya dengan mencapai penjualan setinggi tingginya akan berdampak pada tingginya laba operasi. Sedangkan fokus yang kedua yaitu bagaimana dengan menggunakan total aset perusahaan dapat mencapai penjualan setinggi tingginya.

Asymp. Sig. (2-tailed)

$$
0,005
$$

Dengan menggunakan uji Wilxocon, menujukkan bahwa return on equity secara keseluruhan, baik sebelum maupun sesudah akuisisi berbeda secara signifikan

\subsection{Net Profit Margin.}

Net profit margin, menunjukkan besarnya laba bersih setelah pajak yang dihasilkan oleh penjualan, semakin tinggi net profit margin berarti menunjukkan bahwa perusahaan semakin efisien.

Tabel 4.3. Net Profit Margin Perusahaan Yang terdaftar di Bursa Efek Indonesia Tahun 2011-2017 (000 000)

\begin{tabular}{|l|l|l|l|l|l|l|l|l|}
\hline \multirow{2}{*}{ No } & \multirow{2}{*}{ Kode } & \multirow{2}{*}{ Perusahaan } & \multicolumn{7}{|c|}{ Tahun } \\
\cline { 5 - 9 } & & 2011 & 2012 & 2013 & 2015 & 2016 & 2017 \\
\hline 1. & AALI & PT Astra & 0,23 & 0,22 & 0,15 & 0,05 & 0,15 & 0,12 \\
\hline 2 & AISA & PT.Tiga P & 0,09 & 0,09 & 0,09 & 0,06 & 0,11 & $-0,17$ \\
\hline 3. & APLN & PT.Agung.P & 0,25 & 0,72 & 1,82 & 0,19 & 0,16 & 0,07 \\
\hline 4. & ASII & PT Astra I & 0,13 & 0,25 & 0,23 & 0,19 & 0,13 & 0,11 \\
\hline 5. & PTBA & PT.Bukit A & 0,29 & 0,25 & 0,14 & 0,15 & 0,14 & 0,23 \\
\hline 6. & MDLN & PT Modernland & 0,15 & 0,25 & 1,33 & 0,03 & 2,03 & 0,20 \\
\hline 7. & XL & PT.XL Asia & 0,12 & 0,13 & 0,05 & $-0,01$ & 0,08 & 0,02 \\
\hline 8. & INTP & PT Indocement & 0,26 & 0,28 & 0,22 & 0,24 & 0,25 & 0,13 \\
\hline 9. & SIMP & PT Salim Ivo & 0,18 & 0,11 & 0,05 & 0,03 & 0,04 & 0,04 \\
\hline 10. & META & PT.Nusantara & $-0,12$ & 0,18 & 0,19 & 0,34 & 0,22 & 0,12 \\
\hline
\end{tabular}

Sumber : Bursa Efek Indonesia (Data Diolah). 
Pada tabel 4.3. nampak bahwa net profit margin perusahaan yang terdaftardi Bursa Efek Indonesia tahun 2011-2017, baik sebelum maupun sesudah akuisisi berfluktuasi. Untuk meningkatkan net profit margin, fokus utamanya untuk meningkatkan earning power, yaitu melalui profit margin dan operating aset turn over, antara lain meningkatkan penjualan, menaikkan harga jual perunit, menambah modal usaha dan menurunkan penjualan sampai volume tetentu.

$$
\begin{array}{|l|l|}
\hline \text { Asymp. Sig. (2-tailed) } & 0,004 \\
\hline
\end{array}
$$

Dengan menggunakan uji Wilxocon, menujukkan bahwa net profit margin secara keseluruhan baik sebelum maupun sesudah akuisisi berbeda secara signifikan

\subsection{Total Aset Turn Over.}

Total aset turn over, menunjukkan seberapa besar satuan penjualan yang dihasilkan setiap satuan total aset.

Tabel 4.4. Total Aset Turn Over Perusahaan Yang Terdaftar di Bursa Efek Indonesia. Tahun 2011-2017 (000 000)

\begin{tabular}{|l|l|l|l|l|l|l|l|l|}
\hline \multirow{2}{*}{ No } & \multirow{2}{*}{ Kode } & \multirow{2}{*}{ Perusahaan } & \multicolumn{7}{|c|}{ Tahun } \\
\cline { 5 - 9 } & & 2011 & 2012 & 2013 & 2015 & 2016 & 2017 \\
\hline 1. & AALI & PT Astra & 1,07 & 0,94 & 0,86 & 0,62 & 0,59 & 0,70 \\
\hline 2 & AISA & PT.Tiga P & 0,49 & 0,71 & 0,81 & 0,66 & 0,71 & 0,56 \\
\hline 3. & APLN & PT.Agung.P & 0,10 & 0,15 & 0,06 & 0,24 & 0,23 & 0,41 \\
\hline 4. & ASII & PT Astra I & 0,12 & 0,23 & 0,23 & 0,21 & 0,15 & 0,70 \\
\hline 5. & PTBA & PT.Bukit A & 0,93 & 0,91 & 1,12 & 0,82 & 0,76 & 0,89 \\
\hline 6. & MDLN & PT Modernland & 0,20 & 0,23 & 0,19 & 0,24 & 0,17 & 0,22 \\
\hline 7. & XL & PT.XL Asia & 0,72 & 0,60 & 0,53 & 0,39 & 0,39 & 0,41 \\
\hline 8. & INTP & PT Indocement & 0,77 & 0,75 & 0,86 & 0,65 & 0,52 & 0,50 \\
\hline 9. & SIMP & PT Salim Ivo & 0,49 & 0,51 & 0,47 & 0,44 & 0,45 & 0,48 \\
\hline 10. & META & PT.Nusantara & 0,13 & 0,13 & 0,17 & 0,13 & 0,18 & 0,156 \\
\hline
\end{tabular}

Sumber : Bursa Efek Indonesia (Data Diolah). 
Pada tabel 4.4. nampak bahwa, total aset turn over perusahaan baik sebelum maupun sesudah akuisisi umumnya berfluktuasi, hal ini menunjukkan bahwa setiap satuan penjualan yang dihasilkan setiap satuan aset perusahaan kurang maksimal. Adapun fokus utama untuk meningkatkan total aset turn over, yaitu dengan jalan meningkatkan profit margin serta operating aset turn over, jadi daharapkan dapat meningkatkan efisiensi setinggi tingginya.

\begin{tabular}{|l|c|}
\hline Asymp. Sig. (2-tailed) & 0,059 \\
\hline
\end{tabular}

Dengan menggunakan uji Wilxocon, menujukkan bahwa total aset turn over secara keseluruhan, baik sebelum maupun sesudah akuisisi berbeda secara signifikan

\section{KESIMPULAN-SARAN :}

a. Kesimpulan :

1. Dari hasil analisis return on investment, return on equity, net profit margin dan total aset turn over baik sebelum maupun sesudah akuisisi, menunjukkan hasil yang berfluktuasi dan mempunyai kecenderungan menurun.

2. Dari uji $\mathrm{T}$ menunjukkan bahwa return on investment, return on equity, net profit margin dan total aset turn over baik sebelum maupun sesudah akuisisi terdapat perbedaan nyata.

3. Pada saat melakukan akuisisi perusahaan berada pada posisi puncak return on investment, return on equity, net profit margin dan total aset turn over, sehingga akusisi hanya merupakan alat untuk mempertahankan hidup atau memperkuat diri.

b. Saran :

1. Perlu adanya ehati hatian bagi perushaan yang mau melakukan akuisisi, walaupun permulaan tahun sesudah akuisisi mengalami pertumbuhan return on investment, return on equity, net profit margin dan total aset turn over namun secara keseluruhan setelah melakukan akuisisi berfluktuasi dan mempunyai kecenderungan menurun, dan berbeda nyata. 
2. Perusahaan yang melakukan akuisisi harus fokus meingkatkan efisiensi, sehingga retabilitas ekonomi dapat tercapai dan dapat meningkatkan rentabilitas secara keseluruhan dimasa yang akan datang

\section{DAFTAR PUSTAKA :}

Agus Sartono, 2001, Manajemen Keuangan, Edisi Keempat, BPFE, Yogyakarta.

Baritwan, 1997, Alat Analisa Keuangan , Edisi Keenam, Penerbit BPFE, LMP2M, Amp Yogjakarta.

Bambang Riyanto, 2001, Dasar-Dasar Pembelanjaan Perusahaan, Edisi Keempat, BPFE, Yogyakarta

Briham, Eugane F. and J.F.Houston, 2001, Manajemen Keuangan, Edisi 8, Erlangga, Jakarta

Copeland Thomas E,2001;Manajemen Keuangan ,edisi 8,Erlangga,Jakarta

Mamduh, 1996, Analisa Laporan Keuangan, Edisi Keempat, Penerbit BPFE Yogjakarta.

Suad Husnan, 1993, Pembelanjaan Perusahaan (Dasar-Dasar Manajemen Keuangan), Liberty, YogYakarta.

Syafarudin Alwi, 1991, Alat-Alat Analisa Dalam Pembelanjaan, Edisi Revisi,Andi Offset, Yogyakarta 